\title{
Non-contiguous finished genome sequence and description of Halopiger goleamassiliensis sp. nov.
}

\author{
Hassani Imene Ikram¹, Robert Catherine ${ }^{2}$, Michelle Caroline ${ }^{2}$, Raoult Didier ${ }^{2}$, Hacène \\ Hocine $^{1^{*}}$, Desnues Christelle ${ }^{2^{*}}$ \\ ${ }^{1}$ USTHB Université, Laboratoire de Biologie Cellulaire et Moléculaire, Faculté de Biologie \\ Algérie \\ * Correspondence: Desnues Christelle (christelle.desnues@univ-amu.fr ) and Hacène Hocine \\ (h_hacene@yahoo.fr)
}

Keywords: Halopiger goleamassiliensis; Draft genome; Euryarchaeota; Extreme halophile; Thermotolerant

Halopiger goleamassiliensis strain $\mathrm{IIH} 3^{\top}$ sp. nov. is a novel, extremely halophilic archaeon
within the genus Halopiger. This strain was isolated from an evaporitic sediment in El Golea
Lake, Ghardaïa region (Algeria). The type strain is strain $\mathrm{IH}^{\mathrm{T}}$. H. goleamassiliensis is moder-
ately thermophilic, neutrophilic, non-motile and coccus-shaped. Here we describe the fea-
tures of this organism, together with the complete genome sequence and annotation. The
$3,906,923$ bp long genome contains 3,854 protein-encoding genes and 49 RNA genes (1
gene is $16 \mathrm{~S}$ rRNA, 1 gene is $23 \mathrm{~S}$ rRNA, 3 genes are $5 \mathrm{~S}$ rRNA, and 44 are tRNA genes).

\section{Introduction}

Halopiger goleamassiliensis sp. nov. strain $\mathrm{IIH}^{\mathrm{T}}$ $(=\mathrm{KC} 430940=$ CSUR P3036 = DSM on-going deposit) is the type strain of $H$.goleamassiliensis $\mathrm{sp}$. nov. This organism is a Gram-negative, extremely halophilic, moderately thermophilic and strictly aerobic archaeon. It was isolated from an evaporitic sediment in El Golea Lake, Ghardaïa region (Algeria) as part of a project studying archaeal diversity in hypersaline Lakes of Algeria.

The number of genera and species belonging to Halobacteria (Archaea, Euryarchaeota) has increased recently due to studies of several different hypersaline environments (thalassohaline and athalassohaline) combined with the use of different isolation media and culture conditions [1]. At the time of writing, the family Halobacteriaceae, the single family described within the order Halobacteriales, accommodated 40 recognized genera [2]. The genus Halopiger was proposed by Gutiérrez et al. (2007) [3] and contains only three species, Halopiger xanaduensis isolated from the Shangmatala Lake (China) [3], Halopiger aswanensis isolated from a hypersaline soil in Aswan (Egypt) [4] and Halopiger salifodinae recently isolated from a salt mine in Kuche county, Xinjiang province, China [5]. So far, this genus is composed of strictly aerobic, Gram-negative, polymorphic and pigmented strains. We have recently used [618] a polyphasic approach for prokaryotic classification [19] that includes genomic data $[20,21]$, MALDI-TOF spectra [22,23] and major phenotypic characteristics.

Using this approach, we report here a summary classification and a set of features for Halopiger goleamassiliensis sp.nov. strain $\mathrm{IIH}^{\mathrm{T}}$ together with the description of the complete genomic sequencing and annotation. These characteristics support the circumscription of the $H$. goleamassiliensis species.

\section{Classification and features}

$H$. goleamassiliensis was isolated from an evaporitic sediment of the hypersaline Lake El Golea in Ghardaïa region of Algeria. The sediment sample (1g) was enriched in a liquid SG medium [24] containing ampicillin $(100 \mu \mathrm{g} / \mathrm{mL})$ at $55^{\circ} \mathrm{C}$ on a rotary shaking platform (150 rpm) for 7 to 15 days. Serial dilutions of enrichment cultures were plated on SG agar plates and incubated aerobically at $55^{\circ} \mathrm{C}$. After 2 to 6 weeks of incubation, representative colonies were picked and maintained in the SG medium at $55^{\circ} \mathrm{C}$. Strain IIH3 ${ }^{\mathrm{T}}$ (Table 1 ) was isolated in 2012 by cultivation in aerobic condi- 
tions at $55^{\circ} \mathrm{C}$ and stored at $-80{ }^{\circ} \mathrm{C}$ with $25 \%(\mathrm{v} / \mathrm{v})$ glycerol.

Genomic DNA was extracted and purified using the Genomic DNA purification kit (MACHEREYNAGEL) Hoerd, France. The 16S rRNA gene was amplified by PCR using the primers 21AF: TTCCGGTTGATCCTGCCGGA and RP2: ACGGCTACCTTGTTACGACTT. A total of 1,444 bases were identified. The sequence was compared with available sequences in GenBank using a BLAST search [36]. The strain exhibited 96\% nu- cleotide sequence similarities with Halopiger xanaduensis [3]. These values were lower than the 98.7\% 16S rRNA gene sequence threshold recommended by Stackebrandt and Ebers to delineate a new species without carrying out DNA-DNA hybridization [37]. A phylogenetic tree (Figure 1) was constructed using the neighbor-joining method with the MEGA 5 program package [38] after multiple alignments of the data using MUSCLE [39]. Evolutionary distances were calculated using the Tamura-Nei model [40].

Table 1. Classification and general features of Halopiger goleamassiliensis according to the MIGS recommendations [25].

\begin{tabular}{|c|c|c|c|}
\hline MIGS ID & Property & Term & Evidence code $^{\mathrm{a}}$ \\
\hline & \multirow{8}{*}{ Current classification } & Domain Archaea & TAS [26] \\
\hline & & Phylum Euryarchaeota & TAS [27] \\
\hline & & Class Halobacteria & TAS $[28,29]$ \\
\hline & & Order Halobacteriales & TAS [30-32] \\
\hline & & Family Halobacteriaceae & TAS $[33,34]$ \\
\hline & & Genus Halopiger & TAS [3] \\
\hline & & Species Halopiger goleamassiliensis & IDA \\
\hline & & Type strain $\mathrm{IIH}^{\mathrm{T}}$ & IDA \\
\hline & Gram stain & Negative & IDA \\
\hline & Cell shape & Coccus & IDA \\
\hline & Motility & Non-motile & IDA \\
\hline & Sporulation & None & IDA \\
\hline & Temperature range & Thermophile, between $40^{\circ} \mathrm{C}$ and $60^{\circ} \mathrm{C}$ & IDA \\
\hline & Optimum temperature & $55^{\circ} \mathrm{C}$ & IDA \\
\hline MIGS-6.3 & Salinity & Halophile, $22.5 \%-25 \%$ (optimum) & IDA \\
\hline \multirow[t]{3}{*}{ MIGS-22 } & Oxygen requirement & Aerobic & IDA \\
\hline & Carbon source & Sugar or amino acids & IDA \\
\hline & Energy metabolism & Heterotrophic & IDA \\
\hline MIGS-6 & Habitat & Salt Lake sediment & IDA \\
\hline MIGS-15 & Biotopic relationship & Free living & IDA \\
\hline \multirow[t]{3}{*}{ MIGS-14 } & Pathogenicity & Non-pathogenic & NAS \\
\hline & Biosafety level & 1 & NAS \\
\hline & Isolation & Sediment of El Golea Lake & IDA \\
\hline MIGS-4 & Geographic location & Algeria & IDA \\
\hline MIGS-5 & Isolation time & 2012 & IDA \\
\hline MIGS-4.1 & Latitude & $30-34 \mathrm{~N}$ & IDA \\
\hline MIGS-4.2 & Longitude & $002-52 \mathrm{E}$ & IDA \\
\hline MIGS-4.3 & Depth & Surface & IDA \\
\hline MIGS-4.4 & Altitude & 397 & IDA \\
\hline
\end{tabular}

${ }^{a}$ Evidence codes - IDA: Inferred from Direct Assay; TAS: Traceable Author Statement (i.e., a direct report exists in the literature); NAS: Non-traceable Author Statement (i.e., not directly observed for the living, isolated sample, but based on a generally accepted property for the species, or anecdotal evidence). These evidence codes are from the Gene Ontology project [35]. If the evidence is IDA, then the property was directly observed for a live isolate by one of the authors or an expert mentioned in the acknowledgements. 


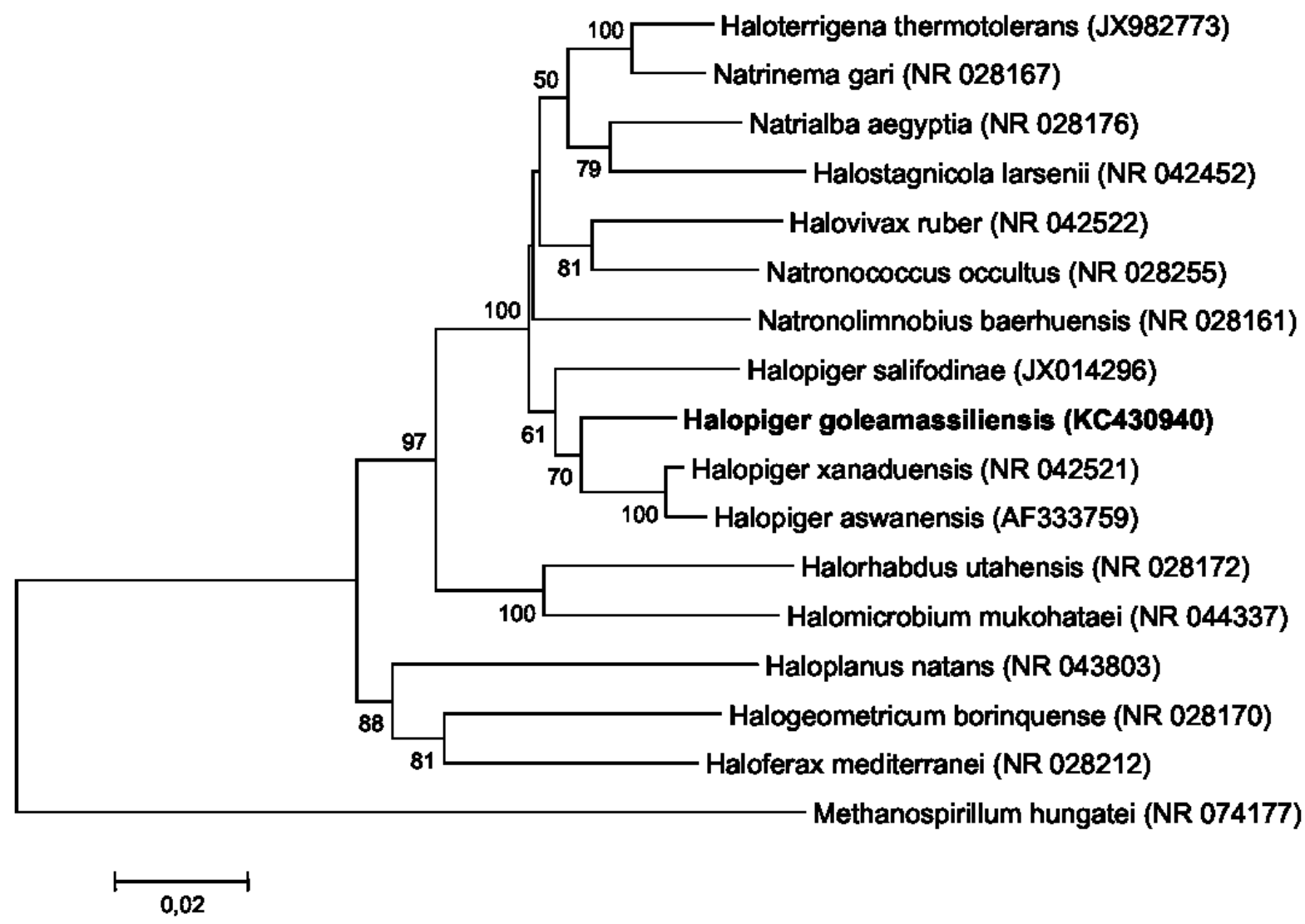

Figure 1. Neighbor-joining phylogenetic tree based on 16S rRNA gene sequence comparisons, showing the position of strain $1 \mathrm{IH} 3^{\top}$ and other related haloarchaeal species. GenBank accession numbers are indicated in parentheses. Sequences were aligned using MUSCLE, and phylogenetic inferences obtained using the MEGA software. Numbers at the nodes are from a bootstrap analysis done using 1,000 replicates to generate a majority consensus tree. Methanospirillum hungatei was used as outgroup.

Phenotypic characterization was carried out according to the recommended minimal standards for the description of new taxa in the order Halobacteriales [41]. Table 2 summarizes the differential phenotypic characteristics of $H$. goleamassiliensis sp. nov. IIH3 ${ }^{\mathrm{T}}$, H. xanaduensis SH6T, $H$. aswanensis $56^{\mathrm{T}}$ and $H$. salifodinae KCY076B2T. Different growth temperatures (30, $\left.37,40,50,55,60^{\circ} \mathrm{C}\right), \mathrm{pH}$ values $(5,6,7,7.5,8,8.5$, $9,10,11,12)$ and $\mathrm{NaCl}$ concentrations $(0,10,12$, $15,20,22.5,25,30 \% \mathrm{~W} / \mathrm{V}$ ) were tested on strain IIH3 ${ }^{\mathrm{T}}$. Cell growth was observed between $40^{\circ} \mathrm{C}$ and $60^{\circ} \mathrm{C}$ (optimum at $55^{\circ} \mathrm{C}$ ), between $15 \%$ and $30 \% \mathrm{NaCl}$ (optimum at 22.5-25 \% NaCl) and at 7 to $11 \mathrm{pH}$ values (optimum at $\mathrm{pH} 8$ ).

Under optimal growth conditions on SG agar medium and after incubation for $15-20$ days at $55^{\circ} \mathrm{C}$, colonies were salmon pigmented, circular with a diameter of 1-2 mm. Cell morphology and motility were examined by using light microscopy and phase-contrast microscopy. Gram staining was performed using samples fixed with acetic acid, as described by Dussault in 1955 [42]. Cells are Gram-negative, cocci (Figure 2) measuring 0.8-1.5 $\mu \mathrm{m}$ in diameter (Figure 3). Motility and spores or capsules were not observed. All the following biochemical and nutritional tests were realized in duplicate. Strain $\mathrm{IIH}^{\mathrm{T}}$ was found to be oxidaseand catalase- positive. The strain is extremely halophilic and cell lysis is observed in distilled water. It is a strictly aerobic organism and anaerobic growth does not occur even in the presence of $\mathrm{KNO}_{3}$ or arginine. Neither magnesium nor amino acids are required for growth. Tween 80 , gelatin, and lipids from egg yolk are hydrolysed, whereas urea, starch, casein, and phosphatase are not. Production of indole and methyl red, VogesProskauer and Simmons' citrate tests are negative. $\mathrm{H}_{2} \mathrm{~S}$ is not produced from cysteine. 


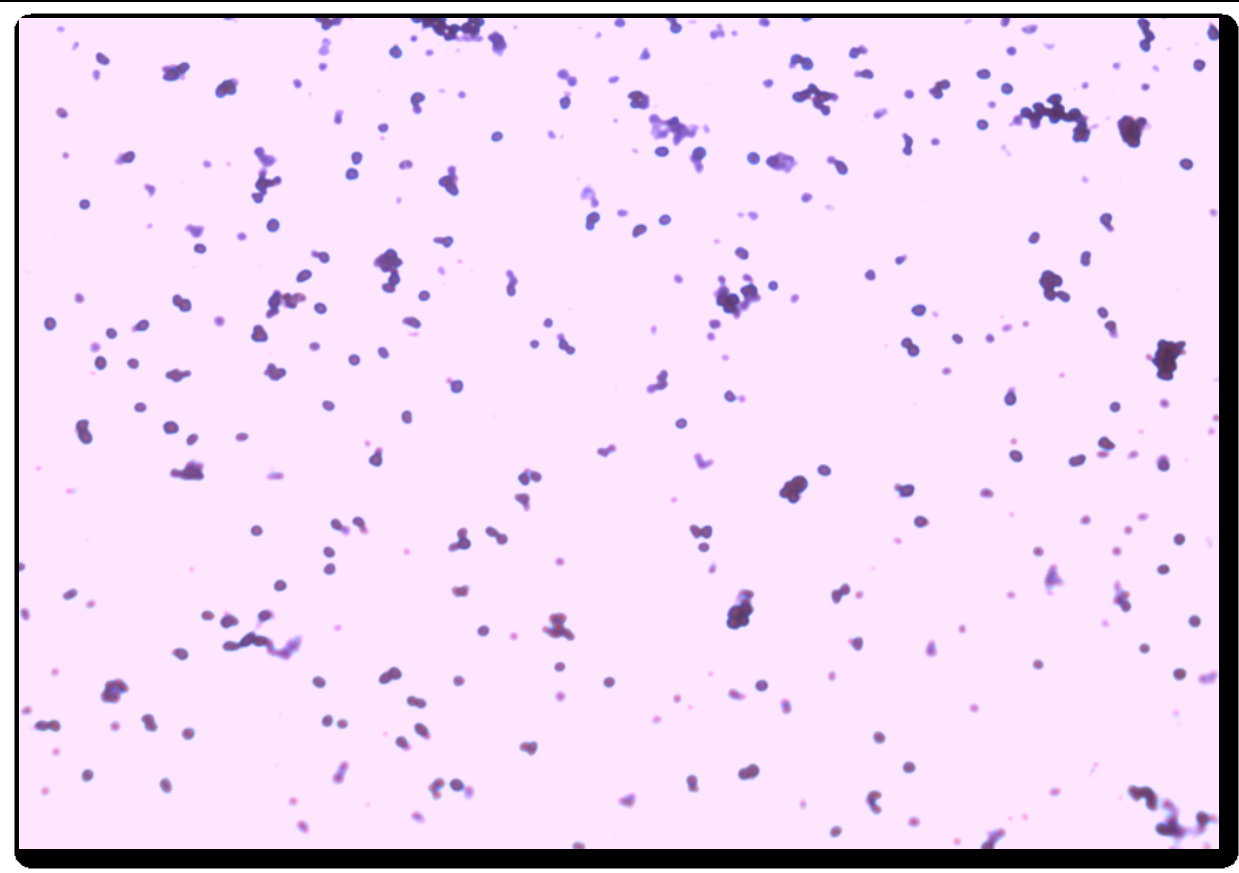

Figure 2. Gram stain of Halopiger goleamassiliensis strain $\mathrm{IIH}^{\mathrm{T}}$.

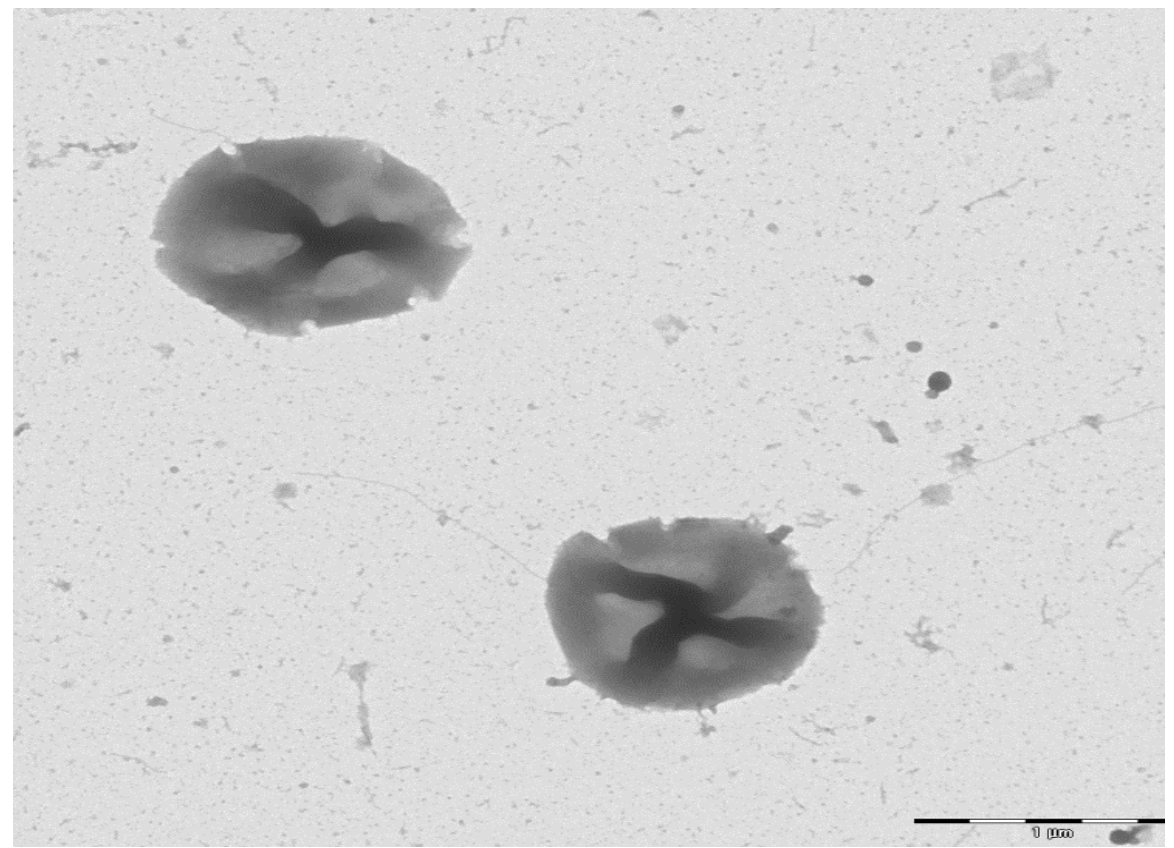

Figure 3. Transmission electron micrograph of $H$. goleamassiliensis strain $\mathrm{IIH} 3^{\top}$, using a Morgani 268D (Philips) at an operating voltage of $60 \mathrm{kV}$. The scale bar represents $1 \mu \mathrm{m}$.

Utilization of carbohydrates and other compounds as sole carbon sources and acid production from these compounds were determined as described by Oren [41]. Several sugars and amino acids can serve as sole carbon and energy sources (Table 2). Antibiotic sensitivity tests were determined on SG medium agar plates with antibiotic discs. Strain IIH3 $^{\mathrm{T}}$ is susceptible to bacitracin $(10 \mu \mathrm{g})$, novobiocin $(30 \mu \mathrm{g})$, streptomycin $(10 \mu \mathrm{g})$ and sulfamethoxazole $(25 \mu \mathrm{g})$, but resistant to ampicillin $(10 \mu \mathrm{g})$, cephalothin $(30 \mu \mathrm{g})$, chloramphenicol $(30 \mu \mathrm{g})$, erythromycin $(15 \mu \mathrm{g})$, gentamicin $(10 \mu \mathrm{g})$, kanamycin $(30 \mu \mathrm{g})$, nalidixic acid $(30 \mu \mathrm{g})$, penicillin $\mathrm{G}(10 \mu \mathrm{g})$, rifampicin $(30 \mu \mathrm{g})$, tetracycline $(30$ $\mu \mathrm{g})$, and vancomycin $(30 \mu \mathrm{g})$. 
Table 2. Differential phenotypic characteristics between strain $\mathrm{IIH} 3^{\top}$ and related species

\begin{tabular}{|c|c|c|c|c|}
\hline Characteristic & H. goleamassiliensis & H. xanaduensis & H. aswanensis & H. salifodinae \\
\hline Cell morphology & coccus & pleomorphic & pleomorphic & pleomorphic rods \\
\hline Cell diameter $(\mu \mathrm{m})$ & $0.8-1.5$ & $0.5-1.0 \times 3.0-13.0$ & $1.25-6.50 \times 0.6-0.9$ & ND \\
\hline Pigmentation & salmon & red & pink & cream \\
\hline Oxygen requirement & strictly aerobic & strictly aerobic & strictly aerobic & strictly aerobic \\
\hline Gram stain & negative & negative & negative & negative \\
\hline $\mathrm{NaCl}$ range $(\%, \mathrm{w} / \mathrm{v})$ & $15-30$ & $15-30$ & $10-30$ & $11-31$ \\
\hline $\mathrm{NaCl}$ optimum $(\%, w / v)$ & $22.5-25$ & 25 & $22.5-25$ & $17-20$ \\
\hline Temperature range $\left({ }^{\circ} \mathrm{C}\right)$ & $40-60$ & $28-45$ & $40-50$ & $25-50$ \\
\hline Temperature optimum $\left({ }^{\circ} \mathrm{C}\right)$ & 55 & 37 & 40 & $37-45$ \\
\hline $\mathrm{pH}$ range & $7-11$ & $6-11$ & $6-9.2$ & $6-8$ \\
\hline $\mathrm{pH}$ optimum & $8-8.5$ & $7.5-8$ & 7.5 & 7.0 \\
\hline Motility & non-motile & non-motile & motile & non-motile \\
\hline Catalase & + & + & + & + \\
\hline \multicolumn{5}{|l|}{ hydrolysis of } \\
\hline Starch & - & - & + & - \\
\hline Tween 80 & + & + & + & - \\
\hline Casein & - & - & - & ND \\
\hline Gelatin & + & + & - & - \\
\hline Lipids from egg yolk & + & ND & - & ND \\
\hline \multicolumn{5}{|l|}{ utilization of } \\
\hline D-Glucose & + & + & + & + \\
\hline Galactose & + & + & ND & - \\
\hline D-Xylose & + & + & + & - \\
\hline Lactose & + & - & - & - \\
\hline Fructose & - & - & + & - \\
\hline Starch & - & - & + & + \\
\hline Mannose & + & - & ND & + \\
\hline D-Ribose & + & - & ND & - \\
\hline Sucrose & - & ND & + & ND \\
\hline Rhamnose & + & ND & ND & - \\
\hline Mannitol & - & - & ND & ND \\
\hline Citrate & - & - & ND & - \\
\hline L-Arginine & - & - & - & - \\
\hline Indole production & - & - & + & - \\
\hline Urease & - & + & - & - \\
\hline $\mathrm{H} 2 \mathrm{~S}$ production & - & - & + & + \\
\hline
\end{tabular}

Strains: H. goleamassiliensis sp. nov. IIH3 ${ }^{\mathrm{T}}$; H. xanaduensis SH-6T; 3, H. aswanensis; H. salifodinae KCY076B2 ${ }^{\mathrm{T}}$. +: Positive result, -: Negative result, ND: Not Determined

Matrix-assisted laser desorption/ionization timeof-flight mass spectrometry (MALDI-TOF MS is considered a reliable and rapid identification method for extremophilic prokaryotes [22,23] and it is used in the present study to characterize the strain $\mathrm{IIH}^{\mathrm{T}}$ as previously described [6-18]. A pipette tip was used to pick one isolated archaeal colony from a culture agar plate, and to spread it as a thin film on a MTP 384 MALDI-TOF tar-get plate (Bruker Daltonics, Leipzig, Germany). The colonies from strain $\mathrm{IIH}^{\mathrm{T}}$ and from other species of archaea were spotted in triplicate. After airdrying, $1.5 \mu \mathrm{l}$ of matrix solution (a saturated solution of $\alpha$-cyano-4-hydroxycinnaminic acid [CHCA] 
in $50 \%$ aqueous acetonitrile containing $2.5 \%$ trifluoroacetic acid) per spot was applied and allowed to dry for five minutes.

Mass spectrometric measurements were performed with a Microflex spectrometer (Bruker). Spectra were recorded in the positive linear mode for the mass range of 2000 to 20,000 DA. The acceleration voltage was $20 \mathrm{kV}$. The time of acquisition was between 30 seconds and 1 minute per spot. Spectra were collected as a sum of 240 shots across a spot. Preprocessing and identification steps were performed using the manufacturer's parameters. The IIH3 $^{\mathrm{T}}$ spectrum (Figure 4) was imported into the MALDI BioTyper software (version 2.0, Bruker) and analyzed by standard pattern matching (with default parameter settings) against the spectra of Haloferax mediterranei,
Natrinema gari, Natrinema pallidum, Haloterrigena thermotolerans, Haloterrigena. sp, Halogeometricum. sp, Haloarcua. sp and Halopiger. $s p$ used as reference data in the BioTyper database (Figure 5).

A score enabled the identification, or not, from the tested species: a score $>2.3$ with a validly published species enabled the identification at the species level, a score $>1.7$ but $<2$ enabled the identification at the genus level; and a score $<1.7$ did not enable any identification. For strain IIH3T, none of the obtained scores was $>1$, thus suggesting that our isolate was not a member of a known species. We added the spectrum from strain IIH3 ${ }^{\mathrm{T}}$ to our database for future reference. Figure 5 shows the MALDI-TOF MS spectrum differences between H. goleamassiliensis and other Archaea.

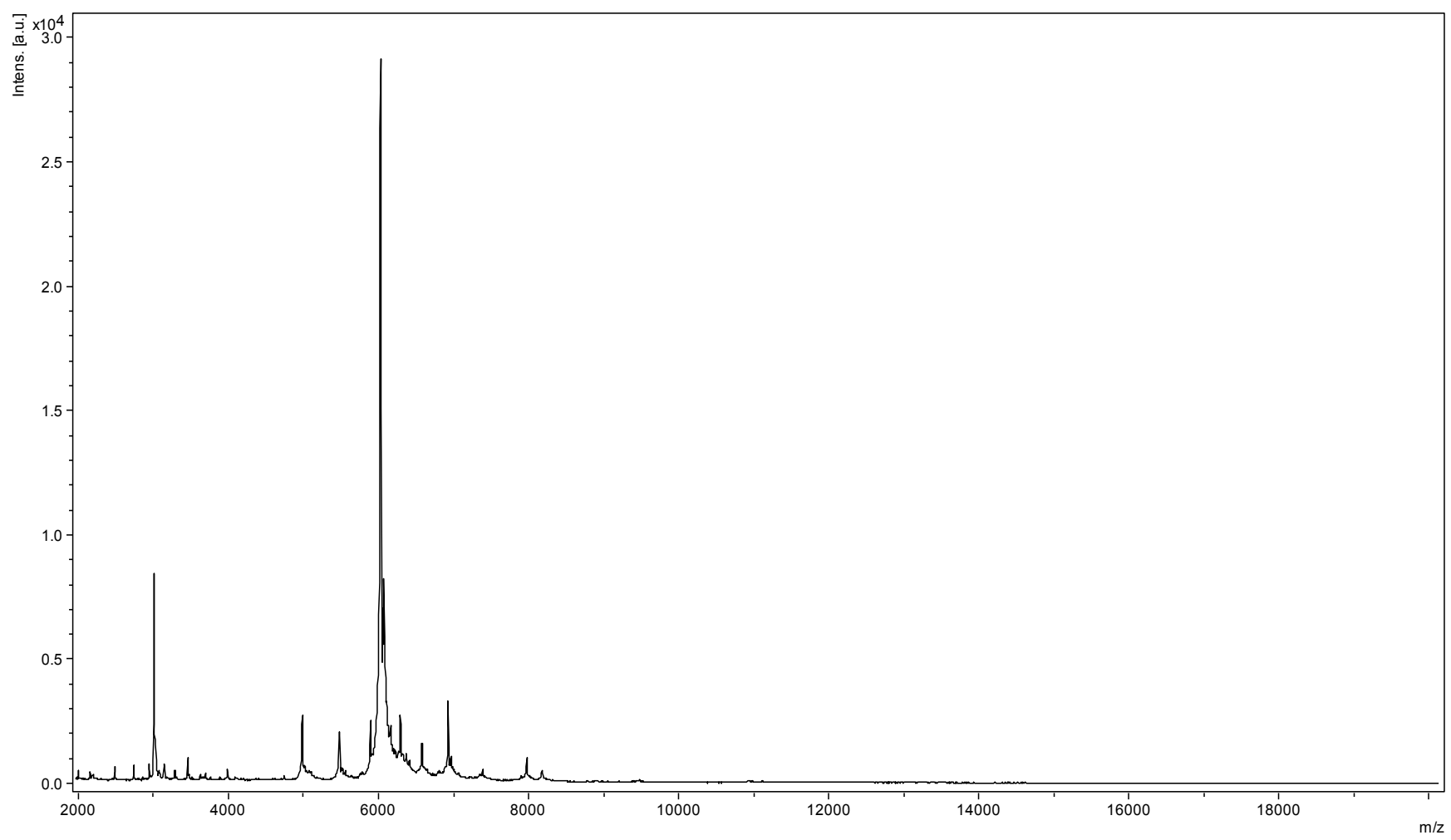

Figure 4: Reference mass spectrum from H. goleamassiliensis strain $\mathrm{IIH}^{\top}$. Spectra from 12 individual colonies were compared and a reference spectrum was generated.

\section{Genome sequencing information Genome project history}

The organism was selected for sequencing on the basis of its phylogenetic position and 16S rRNA similarity to other members of the genus Halopiger, and as part of a study of archaeal diversity in hypersaline lakes of Algeria. It is the second genome of a Halopiger species and the first se- quenced genome of $H$. goleamassiliensis sp. nov. The EMBL accession number is CBMB010000001CBMB010000011 and it consists of 3 scaffolds (HG315690-HG315692). A summary of the project information (PRJEB1780) and its association with MIGS version 2.0 recommendations [27] is shown in Table 3. 


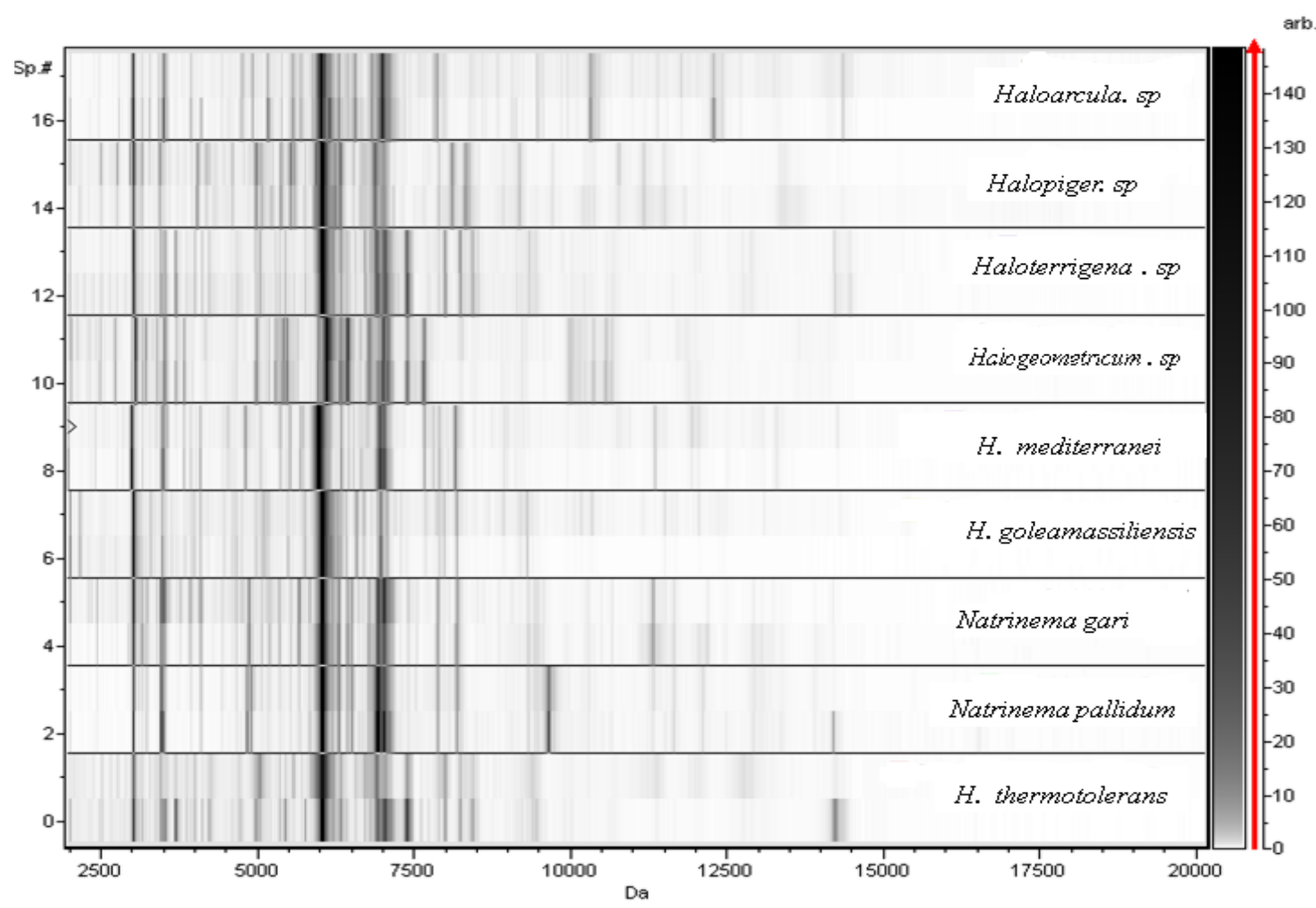

Figure 5. Gel view comparing the H. goleamassiliensis strain $\mathrm{IIH} 3^{\top}$ spectrum with those of other archaea. The Gel View displays the raw spectra of all loaded spectrum files arranged in a pseudo-gel like look. The x-axis records the $\mathrm{m} / \mathrm{z}$ value. The left $\mathrm{y}$-axis displays the running spectrum number originating from subsequent spectra loading. The peak intensity is expressed by the gray scale intensity. The scale shown on the right $y$ axis links the color to the peak intensity in arbitrary units.

\section{Growth conditions and DNA isolation}

H. goleamassiliensis sp.nov. strain IIH3 ${ }^{\mathrm{T}}$ (= CSUR P3036 =DSM on-going deposit) was grown in SG medium at $55^{\circ} \mathrm{C}$ in aerobic condition. DNA was isolated and purified using the Genomic DNA purification kit, NucleoSpin Tissue procedure (MACHEREY-NAGEL) following the standard protocol as recommended by the manufacturer. The quality of the DNA was checked on an agarose gel $(0.8 \%)$ stained with SYBR safe. The yield and the concentration were measured by the Quant-it Picogreen Kit (Invitrogen) on the Genios Tecan Fluorometer at $33.1 \mathrm{ng} / \mu \mathrm{L}$.

\section{Genome sequencing and assembly}

A $5 \mathrm{~kb}$ paired-end sequencing strategy (Roche, Meylan, France) was used. This project was loaded on a $1 / 4$ region on PTP Picotiterplate (Roche). Three $\mu$ g of DNA was mechanically fragmented on the Covaris device (KBioScience-LGC Genomics, Teddington, UK) using miniTUBE-Red $5 \mathrm{~Kb}$. The DNA fragmentation was visualized through an Agilent 2100 BioAnalyzer on a DNA labchip 7500 with an optimal size of $4.7 \mathrm{~kb}$. The library was constructed according to the 454 GS FLX Titanium paired end-protocol. After PCR amplification through 17 cycles followed by double size selection, the single stranded paired-end library was then loaded on a DNA labchip RNA pico 6000 on the BioAnalyzer. The pattern showed an optimum at $480 \mathrm{bp}$ and the concentration was quantified on a Genios Tecan fluorometer at $642 \mathrm{pg} / \mu \mathrm{L}$. The concentration equivalence of the library was calculated at $10^{8}$ molecules $/ \mu \mathrm{L}$. The library was stored at $-20^{\circ} \mathrm{C}$ until further use, and amplified in stored at $-20^{\circ} \mathrm{C}$ until further use, and amplified in 2 emPCR reactions at $0.25 \mathrm{cpb}$, in 2 emPCR at 0.5 $\mathrm{cpb}$ and in $2 \mathrm{emPCR}$ at $1 \mathrm{cpb}$ with the GS Titanium SV emPCR Kit (Lib-L) v2 (Roche). The yield of the 3 types of paired-end emPCR reactions was $3.68 \%, 8.05 \%$ and $10.69 \%$ respectively, in the quality range of 5 to $20 \%$ expected from the Roche procedure. These emPCR were pooled. Both libraries were loaded onto GS Titanium PicoTiterPlates (PTP Kit $70 \times 75$, Roche) and pyrosequenced with the GS Titanium Sequencing Kit XLR70 (Roche). The run was performed overnight and then analyzed on the cluster through the gsRunBrowser and Newbler assembler (Roche). 


\begin{tabular}{lll} 
Table 3. Project information & \\
\hline MIGS ID & Property & Term \\
\hline MIGS-31 & Finishing quality & High-quality draft \\
MIGS-28 & Libraries used & Paired-end 5 kb library \\
MIGS-29 & Sequencing platforms & 454 GS FLX Titanium \\
MIGS-31.2 & Fold coverage & $21.6 \times$ \\
MIGS-30 & Assemblers & Newbler version 2.5.3 \\
MIGS-32 & Gene calling method & Prodigal \\
& EMBL ID & CBMB010000001- \\
& EMBL Date of Release & CBMB010000011 \\
& June 18, 2018 \\
& Project relevance & Study of the archaeal diversity in \\
& hypersaline lakes of Algeria \\
\hline
\end{tabular}

A total of 271,702 filter-passed wells were obtained and generated $84.39 \mathrm{Mb}$ with an average length of $325 \mathrm{bp}$. The passed filter sequences were assembled using Newbler with $90 \%$ identity and $40 \mathrm{bp}$ overlap. The final assembly contained 12 contigs (11 large contigs $>1500 \mathrm{bp}$ ) arranged in 3 scaffolds and generated a genome size of $3.9 \mathrm{Mb}$, which corresponds to a coverage of $21.6 \times$ genome equivalent.

\section{Genome annotation}

Open Reading Frames (ORFs) were predicted using prodigal with default parameters [43]. ORFs spanning a sequencing gap region were excluded. Assessment of protein function was obtained by comparing the predicted protein sequences with sequences in the GenBank [44] and the Clusters of Orthologous Groups (COG) databases using BLASTP. RNAmmer [45] and tRNAscan-SE 1.21 [46] were used for identifying the rRNAs and tRNAs, respectively. SignalP [47] and TMHMM [48] were used to predict signal peptides and transmembrane helices, respectively. For alignment lengths greater than 80 amino acids, ORFans were identified if their BLASTP E-value was lower than 1e-03. An E-value of 1e-05 was used if alignment lengths were smaller than 80 amino acids. DNA Plotter [49] was used for visualization of genomic features and Artemis [50] was used for data management. The mean level of nucleotide sequence similarity was estimated at the genome level between $H$. goleamassiliensis and 5 other members of the Halobacteriaceae family (Table 6), by BLASTN comparison of orthologous ORFs in pairwise genomes. Orthologous proteins were detected using the Proteinortho software using the following parameters: e-value 1e-05, 30\% identi- ty, $50 \%$ coverage and $50 \%$ of algebraic connectivity [51].

\section{Genome properties}

The genome is $3,906,923 \mathrm{bp}$ long and displays a $\mathrm{G}+\mathrm{C}$ content of $66.06 \%$. (Table 4 , Figure 6 ) It is composed of 12 contigs (11 large contigs $>1,500$ bp) arranged into 3 scaffolds. Of the 3,903 predicted genes, 3,854 were protein-coding genes (COG), and 49 were RNAs ( 1 gene is $16 \mathrm{~S}$ rRNA, 1 gene is 23S rRNA, 3 genes are 5S rRNA, and 44 are tRNA genes). A total of 2,359 genes (61.21\%) were assigned a putative function (by COG or by NR BLAST) and 188 genes were identified as ORFans (4.88\%). The remaining genes were annotated as hypothetical proteins (1059 genes = $27.48 \%$ ). The distribution of genes into COG functional categories is presented in Table 4. The properties and the statistics of the genome are summarized in Tables 4 and 5.

\section{Comparison with other genomes}

Currently, only one genome from Halopiger species is available. Here, we compared the genome of H. goleamassiliensis strain IIH3 ${ }^{\mathrm{T}}$ with those of $H$. xanaduensis strain SH-6, Halalkalicoccus jeotgali strain B3, Natronomonas pharaonis strain DSM 2160, Haloterrigena turkmenica strain DSM 5511 and Natrialba magadii strain ATCC 43099. The genome of $H$. goleamassiliensis (3.90 Mb) is larger than that of Halalkalicoccus jeotgali and Natronomonas pharaonis (3.69 and $2.75 \mathrm{Mb}$, respectively) but of a smaller size than $H$. xanaduensis, Natrialba magadii and Haloterrigena turkmenica (4.35, 4.44 and $5.44 \mathrm{Mb}$ respectively). The GC\% content of $H$. goleamassiliensis $(66.06 \%)$ is higher than that of $H$. xanaduensis $(65.2 \%)$, 
Haloterrigena turkmenica (64.26\%),

Natronomonas pharaonis (63.1\%), Halalkalicoccus jeotgali (62.5\%) and Natrialba magadii (61.1\%). $H$. goleamassiliensis has more predicted proteincoding genes $(3,854)$ than Haloterrigena turkmenica, $H$. xanaduensis Natrialba magadii, Halalkalicoccus jeotgali and Natronomonas pharaonis $(3,739,3,588,3,559,3,035$ and 2,659 respectively). In addition, $H$. goleamasiliensis shared a mean genomic sequence similarity of 67.60, 78.21, 76.27, 68.70 and $78.62 \%$ with Natronomonas pharaonis, Haloterrigena turkmenica, Natrialba magadii, Halalkalicoccus jeotgali and Halopiger xanaduensis respectively (Table 6).

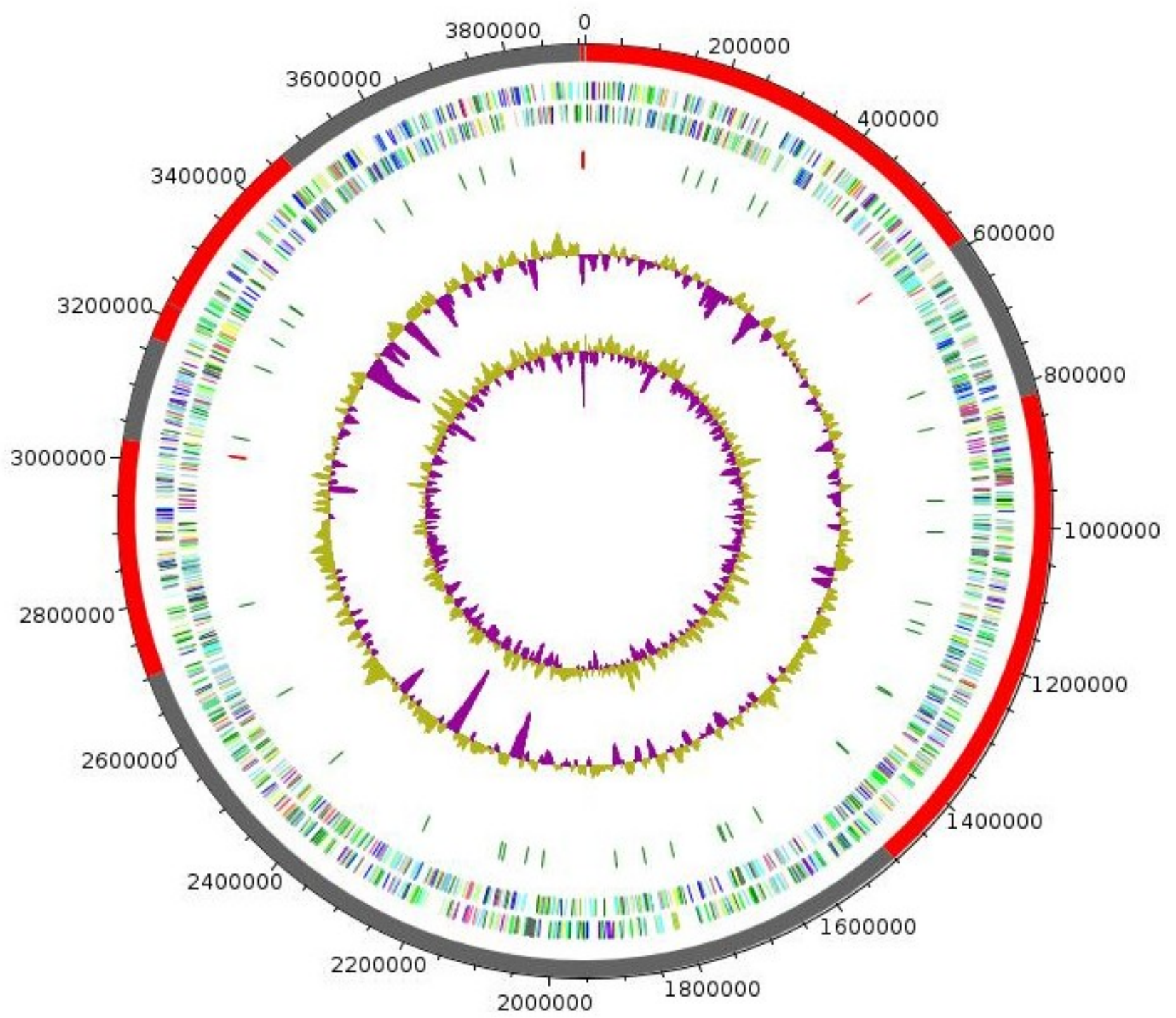

Figure 6. Graphical circular map of the $\mathrm{H}$. goleamassiliensis $\mathrm{IIH} 3^{\mathrm{T}}$ genome. From the outside in: The first circle indicates the scaffolds, the next two circles show open reading frames oriented in the forward and reverse (colored by COG categories) directions, respectively. The fourth circle displays the rRNA gene operon (red) and tRNA genes (green). The fifth circle shows the $\mathrm{G}+\mathrm{C} \%$ content plot. The innermost circle shows the GC skew, purple and olive indicating negative and positive values, respectively. 
Table 4. Nucleotide content and gene count levels of the genome

\begin{tabular}{lrr}
\hline Attribute & Value & \% of total $^{\mathbf{a}}$ \\
\hline Genome size (bp) & $3,906,923$ & 100.00 \\
DNA G+C content (bp) & $2,581,064$ & 66.06 \\
DNA coding region (bp) & $3,359,291$ & 85.98 \\
Total genes & 3,903 & 100.00 \\
RNA genes & 49 & 1.26 \\
Protein-coding genes & 3,854 & 98.74 \\
Genes with function prediction & 2,359 & 61.21 \\
Genes assigned to COGs & 2,446 & 63.47 \\
Genes with peptide signals & 320 & 8.30 \\
Genes with transmembrane helices & 906 & 23.51 \\
\hline
\end{tabular}

${ }^{a}$ The total is based on either the size of the genome in base pairs or the total number of protein coding genes in the annotated genome.

Table 5. Number of genes associated with the 25 general COG functional categories

\begin{tabular}{llll}
\hline Code & \multicolumn{1}{c}{ Value } & \% of total & Description \\
\hline J & 166 & 4.31 & Translation \\
A & 1 & 0.003 & RNA processing and modification \\
K & 157 & 4.07 & Transcription \\
L & 113 & 2.93 & Replication, recombination and repair \\
B & 3 & 0.08 & Chromatin structure and dynamics \\
D & 18 & 0.47 & Cell cycle control, mitosis and meiosis \\
Y & 0 & 0 & Nuclear structure \\
V & 46 & 1.19 & Defense mechanisms \\
T & 128 & 3.32 & Signal transduction mechanisms \\
M & 74 & 1.92 & Cell wall/membrane biogenesis \\
N & 51 & 1.32 & Cell motility \\
Z & 0 & 0 & Cytoskeleton \\
W & 0 & 0 & Extracellular structures \\
U & 27 & 0.70 & Intracellular trafficking and secretion \\
O & 114 & 2.96 & Post-translational modification, protein turnover, chaper- \\
C & 168 & 4.36 & ones \\
G & 122 & 3.17 & Energy production and conversion \\
E & 266 & 6.90 & Carbohydrate transport and metabolism \\
F & 70 & 1.82 & Amino acid transport and metabolism \\
H & 131 & 3.40 & Nucleotide transport and metabolism \\
I & 107 & 2.78 & Coenzyme transport and metabolism \\
P & 176 & 4.57 & Lipid transport and metabolism \\
Q & 82 & 2.13 & Snorganic ion transport and metabolism \\
R & 510 & 13.23 & lism \\
S & 248 & 6.43 & General function prediction only \\
- & 1408 & 36.53 & Function unknown \\
\hline & & & Not in COGs \\
\hline
\end{tabular}


aThe total is based on the total number of protein coding genes in the annotated genome.

Table 6. Orthologous gene comparison and average nucleotide identity of $H$. goleamassiliensis with other compared genomes (upper right, numbers of orthologous genes; lower left, mean nucleotide identities of orthologous genes). Bold numbers indicate the numbers of genes or each genome.

\begin{tabular}{lllllll}
\hline Species (accession number) & $\begin{array}{l}H . \\
\text { goleamassilien } \\
\text { sis }\end{array}$ & $\begin{array}{l}\text { N. } \\
\text { pharaonis }\end{array}$ & $\begin{array}{l}\text { H. } \\
\text { turkmenica }\end{array}$ & N. magadii & $\begin{array}{l}\text { H. jeotgali } \\
\text { xanadue } \\
\text { nsis }\end{array}$ \\
\hline Halopiger goleamassiliensis (PRJEB1780) & $\mathbf{3 8 5 4}$ & 1415 & 2036 & 1859 & 1542 & 2103 \\
Natronomonas pharaonis (NC_007426) & 67.60 & $\mathbf{2 6 5 9}$ & 1393 & 1321 & 1254 & 1381 \\
Haloterrigena turkmenica (NC_013743) & 78.21 & 67.81 & $\mathbf{3 7 3 9}$ & 1765 & 1559 & 2057 \\
Natrialba magadii(NC_013922) & 76.27 & 66.85 & 76.83 & $\mathbf{3 5 5 9}$ & 1442 & 1828 \\
Halalkalicoccus jeotgali (NC_014297) & 68.70 & 67.76 & 68.97 & 67.55 & $\mathbf{3 0 3 5}$ & 1589 \\
Halopiger xanaduensis (NC_015666) & 78.62 & 67.52 & 79.73 & 76.98 & 68.83 & $\mathbf{3 5 8 8}$ \\
\hline
\end{tabular}

\section{Conclusion}

On the basis of phenotypic, phylogenetic and genomic analyses, we formally propose the creation of Halopiger goleamassiliensis sp. nov. that contains the strain IIH3 ${ }^{\mathrm{T}}$. This archaeal strain has been found in Algeria.

\section{Description of Halopiger goleamassiliensis} sp. nov.

Halopiger goleamassiliensis (go.le'a. ma. si. li. en'sis. L. gen. masc. n. goleamassiliensis from the combination of El Golea, the Algerian region where the strain was isolated, and massiliensis, of Massilia, the Latin name of Marseille where the strain was sequenced). It has been isolated from an evaporitic sediment in El Golea Lake, Algeria.

Colonies were smooth, salmon-pigmented and small with 1 to $2 \mathrm{~mm}$ in diameter under optimal growth conditions. Strain is strictly aerobic, extremely halophilic and moderately thermophilic archeon. Growth occurs at $\mathrm{NaCl}$ concentrations of $15-30 \%$, at $\mathrm{pH}$ values in the range 7-11, and within the temperature range $40-60{ }^{\circ} \mathrm{C}$. Optimal $\mathrm{NaCl}$ concentration, $\mathrm{pH}$ and temperature for growth are $22.5-25 \%, 8.0$ and $55{ }^{\circ} \mathrm{C}$, respectively. Magnesium is not required for growth. Cells are coccusshaped (0.8-1.5 $\mu \mathrm{m})$, Gram-negative, non-motile and lyse in distilled water. Cells are positive for catalase, oxidase and lysine decarboxylase production and negative for urease, arginine dihydrolase, ornithine decarboxylase, tryptophanase, phosphatase, $\beta$-galactosidase, Dmannitol, sacharose, starch, dextrose, and D-

\section{References}

1. Ma Y, Galinski EA, Grant WD, Oren A, Ventosa A. Halophiles 2010: life in saline environments. fructose fermentation. The following substrates are utilized as single carbon and energy sources for growth: pyruvate, D-glucose, D-mannose, Dribose, D-xylose, maltose, sucrose, lactose, casamino acids, bacto-peptone, bacto-tryptone, and yeast extract. Tween 80 , gelatin, and lipids from egg yolk are hydrolysed, whereas urea, starch, and casein are not. Methyl red, VogesProskauer, Simmons' citrate tests, and $\mathrm{H}_{2} \mathrm{~S}$ production are negative.

Cells are susceptible to bacitracin, novobiocin, streptomycin, and sulfamethoxazole but resistant to ampicillin, cephalothin, chloramphenicol, erythromycin, gentamicin, kanamycin, nalidixic acid, penicillin G, rifampicin, tetracycline, and vancomycin.

The $\mathrm{G}+\mathrm{C}$ content of the DNA is $66.06 \%$. The $16 \mathrm{~S}$ rRNA and genome sequences are deposited in GenBank and EMBL under accession numbers KC430940 and CBMB010000001-CBMB010000011 , respectively. The type strain $\mathrm{IIH}^{\mathrm{T}}(=\mathrm{CSUR}$ $\mathrm{P} 3036=$ DSM 27562) was isolated from an evaporitic sediment in El Golea Lake, Algeria.

\section{Acknowledgments}

The authors thank the entire team of Christelle Desnues and more particularly Dr. Nikolay Popgeorgiev for his help with TEM and Sarah Temmam for her help with tree construction. The authors acknowledge the Xegen Company for automating the genomic annotation process.

Appl Environ Microbiol 2010; 76:6971-6981. PubMed http://dx.doi.org/10.1128/AEM.01868-10 
Ikram et al.

2. Euzéby JP. List of prokaryotic names with standing in nomenclature LPSN. 2011; Available at:http://www.bacterio.cict.fr/classifgenerafamilies .html\#Halobacteriaceae. Accessed 23 June 2013.

3. Gutiérrez MC, Castillo AM, Kamekura M, Xue Y, Ma Y, Cowan DA, Jones BE, Grant WD, Ventosa A. Halopiger xanaduensis gen. nov., sp. nov., an extremely halophilic archaeon isolated from saline Lake Shangmatala in Inner Mongolia, China. Int J Syst Evol Microbiol 2007; 57:1402-1407. PubMed http://dx.doi.org/10.1099/ijs.0.65001-0

4. Hezayen FF, Gutiérrez MC, Steinbüchel A, Tindall BJ, Rehm BH. Halopiger aswanensis sp. nov., a polymer-producing and extremely halophilic archaeon isolated from hypersaline soil. Int J Syst Evol Microbiol 2010; 60:633-637. PubMed http://dx.doi.org/10.1099/ijs.0.013078-0

5. Zhang WY, Jr., Meng Y, Zhu XF, Wu M. Halopiger salifodinae sp. nov., an extremely halophilic archaeon isolated from a salt mine. Int J Syst Evol Microbiol 2013. PubMed

6. Lagier JC, El Karkouri K, Nguyen TT, Armougom F, Raoult D, Fournier PE. Non-contiguous finished genome sequence and description of Anaerococcus senegalensis sp. nov. Stand Genomic Sci 2012; 6:116-125. PubMed http://dx.doi.org/10.4056/sigs.2415480

7. Lagier JC, Gimenez G, Robert C, Raoult D, Fournier PE. Non-contiguous finished genome sequence and description of Herbaspirillum massiliense sp. nov. Stand Genomic Sci 2012; 7:200-209. PubMed

8. Hugon P, Mishra AK, Lagier JC, Nguyen TT, Couderc C, Raoult D, Fournier PE. Non contiguous finished genome sequence and description of Brevibacillus massiliensis sp. nov. Stand Genomic Sci 2013; 8:1-14. PubMed http://dx.doi.org/10.4056/sigs.3466975

9. Hugon P, Mishra AK, Robert C, Raoult D, Fournier PE. Non-contiguous finished genome sequence and description of Anaerococcus vaginalis. Stand Genomic Sci 2012; 6:356-365. PubMed http://dx.doi.org/10.4056/sigs.2716452

10. Mishra AK, Hugon P, Robert C, Raoult D, Fournier PE. Non contiguous-finished genome sequence and description of Peptoniphilus grossensis sp. nov. Stand Genomic Sci 2012; 7:320-330. PubMed

11. Kokcha S, Mishra AK, Lagier JC, Million M, Leroy Q, Raoult D, Fournier PE. Non contiguousfinished genome sequence and description ofBacillus timonensis sp. nov. Stand Genomic Sci
2012; 6:346-355. PubMed

http://dx.doi.org/10.4056/sigs.2776064

12. Lagier JC, Armougom F, Mishra AK, Nguyen TT, Raoult D, Fournier PE. Non-contiguous finished genome sequence and description of Alistipes timonensis sp. nov. Stand Genomic Sci 2012; 6:315-324. PubMed

13. Ramasamy D, Kokcha S, Lagier JC, Nguyen TT, Raoult D, Fournier PE. Genome sequence and description of Aeromicrobium massiliense sp. nov. Stand Genomic Sci 2012; 7:246-257. PubMed http://dx.doi.org/10.4056/sigs.3306717

14. Mishra AK, Lagier JC, Robert C, Raoult D, Fournier PE. Non-contiguous finished genome sequence and description of Clostridium senegalense sp. nov. Stand Genomic Sci 2012; 6:386-395. PubMed

15. Lagier JC, Ramasamy D, Rivet R, Raoult D, Fournier PE. Non contiguous-finished genome sequence and description of Cellulomonas massiliensis sp. nov. Stand Genomic Sci 2012; 7:258-270. PubMed http://dx.doi.org/10.4056/sigs.3316719

16. Kokcha S, Ramasamy D, Lagier JC, Robert C, Raoult D, Fournier PE. Non-contiguous finished genome sequence and description of Brevibacterium senegalense sp. nov. Stand Genomic Sci 2012; 7:233-245. PubMed http://dx.doi.org/10.4056/sigs.3256677

17. Mishra AK, Lagier JC, Robert C, Raoult D, Fournier PE. Non contiguous-finished genome sequence and description of Peptoniphilus timonensis sp. nov. Stand Genomic Sci 2012; 7:111. PubMed http://dx.doi.org/10.4056/sigs.2956294

18. Mishra AK, Lagier JC, Rivet R, Raoult D, Fournier $P E$. Non-contiguous finished genome sequence and description of Paenibacillus senegalensis sp. nov. Stand Genomic Sci 2012; 7:70-81. PubMed

19. Tindall BJ, Rosselló-Móra R, Busse HJ, Ludwig W, Kämpfer P. Notes on the characterization of prokaryote strains for taxonomic purposes. Int I Syst Evol Microbiol 2010; 60:249-266. PubMed http://dx.doi.org/10.1099/ijs.0.016949-0

20. Klenk HP, Göker M. En route to a genome-based classification of Archaea and Bacteria. Syst Appl Microbiol 2010; 33:175-182. PubMed http://dx.doi.org/10.1016/j.syapm.2010.03.003

21. Schleifer KH. Classification of Bacteria andArchaea: past, present and future. Syst Appl 
Microbiol 2009; 32:533-542. PubMed

http://dx.doi.org/10.1016/j.syapm.2009.09.002

22. Dridi B, Raoult D, Drancourt M. Matrix-assisted laser desorption/ionization time-of-flight mass spectrometry identification of Archaea : towards the universal identification of living organisms. APMIS 2012; 120:85-91. PubMed http://dx.doi.org/10.1111/j.1600$\underline{0463.2011 .02833 . x}$

23. Krader P, Emerson D. Identification of archaea and some extremophilic bacteria using matrixassisted laser desorption/ionization time-of-flight (MALDI-TOF) mass spectrometry. Extremophiles 2004; 8:259-268. PubMed http://dx.doi.org/10.1007/s00792-004-0382-7

24. Ozcan B, Cokmus C, Coleri A, Caliskan M. Characterization of extremely halophilic archaea isolated from saline environment in different parts of Turkey. Mikrobiologiia. 2006; 75(6): 849-856.

25. Field D, Garrity G, Gray T, Morrison N, Selengut J, Sterk P, Tatusova T, Thomson N, Allen MJ, Angiuoli SV, et al. The minimum information about a genome sequence (MIGS) specification. Nat Biotechnol 2008; 26:541-547; http://www.ncbi.nlm.nih.gov/entrez/query.fcgi?c $\mathrm{md}=$ Retrieve $\& \mathrm{db}=$ PubMed\&list_uids $=18464787 \&$ dopt=Abstract. PubMed http://dx.doi.org/10.1038/nbt1360

26. Woese CR, Kandler O, Wheelis ML. Towards a natural system of organisms: proposal for the domains Archaea, Bacteria, and Eucarya. Proc Natl Acad Sci USA 1990; 87:4576-4579. PubMed http://dx.doi.org/10.1073/pnas.87.12.4576

27. Garrity GM, Holt JG. Phylum AII. Euryarchaeota phy. nov. In: Garrity GM, Boone DR, Castenholz RW (eds), Bergey's Manual of Systematic Bacteriology, Second Edition, Volume 1, Springer, New York, 2001, p. 211-355.

28. List Editor. Validation List no. 85. Validation of publication of new names and new combinations previously effectively published outside the IJSEM. Int J Syst Evol Microbiol 2002; 52:685-690. PubMed http://dx.doi.org/10.1099/ijs.0.02358-0

29. Grant WD, Kamekura M, McGenity TJ, Ventosa A. Class III. Halobacteria class. nov. In: Garrity GM, Boone DR, Castenholz RW (eds), Bergey's Manual of Systematic Bacteriology, Second Edition, Volume 1, Springer, New York, 2001, p. 294.

30. Grant WD, Larsen H. Group III. Extremely halophilic archaeobacteria. Order Halobacteriales ord. nov. In Holt JG (ed), Bergey's Manual of Sys- tematic Bacteriology, Volume 3, Baltimore : Williams \& Wilkins, 1989, p. 2216-2228.

31. Trüper, HG. The nomenclatural types of the orders Acholeplasmatales, Halanaerobiales, Halobacteriales, Methanobacteriales, Methanococcales, Methanomicrobiales, Planctomycetales, Prochlorales, Sulfolobales, Thermococcales, Thermoproteales and Verrucomicrobiales are the genera Acholeplasma, Halanaerobium, Halobacterium, Methanobacterium, Methanococcus, Methanomicrobium, Planctomyces, Prochloron, Sulfolobus, Thermococcus, Thermoproteus and Verrucomicrobium, respectively. Opinion 79. Int J Syst Evol Microbiol 2005; 55:517-518. PubMed http://dx.doi.org/10.1099/ijs.0.63548-0

32. List Editor. Validation List no. 31. Validation of the publication of new names and new combinations previously effectively published outside the IJSB. Int J Syst Bacteriol 1989; 39:495-497. http://dx.doi.org/10.1099/00207713-39-4-495

33. Skerman VBD, McGowan V, Sneath PHA. Approved Lists of Bacterial Names. Int / Syst Bacteriol 1980; 30:225-420. http://dx.doi.org/10.1099/00207713-30-1-225

34. Gibbons NE. Family V. Halobacteriaceae Fam. nov. In: Buchanan RE, Gibbons NE (eds), Bergey's Manual of Determinative Bacteriology, Eighth Edition, The Williams and Wilkins Co., Baltimore, 1974 , p. 269-273.

35. Ashburner M, Ball CA, Blake JA, Botstein D, Butler $\mathrm{H}$, Cherry JM, Davis AP, Dolinski K, Dwight SS, Eppig JT, et al. Gene ontology: tool for the unification of biology. The Gene Ontology Consortium. Nat Genet 2000; 25:25-29. PubMed http://dx.doi.org/10.1038/75556

36. Altschul SF, Madden TL, Schaffer AA, Zhang J, Zhang Z, Miller W, Lipman DJ. Gapped BLAST and PSI-BLAST: a new generation of protein database search programs. Nucleic Acids Res 1997; 25:3389-3402. PubMed http://dx.doi.org/10.1093/nar/25.17.3389

37. Stackebrandt E, Ebers J. Taxonomic parameters revisited: tarnished gold standards. Microbiol Today. 2006; 152-155.

38. Tamura K, Peterson D, Peterson N, Stecher G, Nei M, Kumar S. MEGA5: molecular evolutionary genetics analysis using maximum likelihood, evolutionary distance, and maximum parsimony methods. Mol Biol Evol 2011; 28:2731-2739. $\underline{\text { PubMed }}$ http://dx.doi.org/10.1093/molbev/msr121 
39. Edgar RC. MUSCLE: a multiple sequence alignment method with reduced time and space complexity. BMC Bioinformatics 2004; 5:113. PubMed http://dx.doi.org/10.1186/1471-2105-5-113

40. Tamura K, Nei M. Estimation of the number of nucleotide substitutions in the control region of mitochondrial DNA in humans and chimpanzees. Mol Biol Evol 1993; 10:512-526. PubMed

41. Oren A, Ventosa A, Grant WD. Proposed minimal standards for description of new taxa in the order Halobacteriales. Int J Syst Bacteriol 1997; 47:233238. http://dx.doi.org/10.1099/00207713-47-1$\underline{233}$

42. Dussault HP. An improved technique for staining red halophilic bacteria. J Bacteriol 1955; 70:484485. PubMed

43. Hyatt D, Chen GL, Locascio PF, Land ML, Larimer FW, Hauser LJ. Prodigal: prokaryotic gene recognition and translation initiation site identification. BMC Bioinformatics 2010; 11:119. PubMed http://dx.doi.org/10.1186/1471-2105-11-119

44. Benson DA, Karsch-Mizrachi I, Clark K, Lipman DJ, Ostell J, Sayers EW. GenBank. Nucleic Acids Res 2012; 40:D48-53. PubMed http://dx.doi.org/10.1093/nar/gkr1202

45. Lagesen K, Hallin P, Rodland EA, Staerfeldt HH, Rognes T, Ussery DW. RNAmmer: consistent and rapid annotation of ribosomal RNA genes. Nucleic Acids Res 2007; 35:3100-3108. PubMed http://dx.doi.org/10.1093/nar/gkm160
46. Lowe TM, Eddy SR. tRNAscan-SE: a program for improved detection of transfer RNA genes in genomic sequence. Nucleic Acids Res 1997; 25:955-964. PubMed

47. Bendtsen JD, Nielsen H. von Hiejne G, Brunak S. Improved prediction of signal peptides: SignalP 3.0. J Mol Biol 2004; 340:783-795. PubMed http://dx.doi.org/10.1016/j.jmb.2004.05.028

48. Krogh A, Larsson B, von Heijne G, Sonnhammer EL. Predicting transmembrane protein topology with a hidden Markov model: application to complete genomes. J Mol Biol 2001; 305:567580. PubMed http://dx.doi.org/10.1006/jmbi.2000.4315

49. Carver T, Thomson N, Bleasby A, Berriman M, Parkhill J. DNAPlotter: circular and linear interactive genome visualization. Bioinformatics 2009; 25:119-120. PubMed http://dx.doi.org/10.1093/bioinformatics/btn578

50. Rutherford K, Parkhill J, Crook J, Horsnell T, Rice $\mathrm{P}$, Rajandream MA, Barrell B. Artemis: sequence visualization and annotation. Bioinformatics 2000; 16:944-945. PubMed http://dx.doi.org/10.1093/bioinformatics/16.10.944

51. Lechner M, Findeiss S, Steiner L, Marz M, Stadler PF, Prohaska SJ. Proteinortho: detection of (co)orthologs in large-scale analysis. BMC Bioinformatics 2011; 12:124. PubMed http://dx.doi.org/10.1186/1471-2105-12-124 